and described. As they are being "cut in" it is possible to make a fairly detailed study of the fresh skeleton and other parts of the anatomy-if the investigator is not afraid of blood and grease.

Moreover, the great number of whales of a single species which are taken facilitates in an unequalled way the study of individual variation in colour and proportions, which evidently is greater among some of the large cetaceans than in any other group of mammals.

The opportunities for the observation and collection of specimens given at the shore-stations, which are located in widely separated parts of the world, has made it possible to investigate the theory, advanced some years ago, that most of the species of large whales are cosmopolitan in distribution; that is, that the humpbacks found in the Atlantic differ in no essential respects from those of the Pacific, and that all belong to a single widespread species.

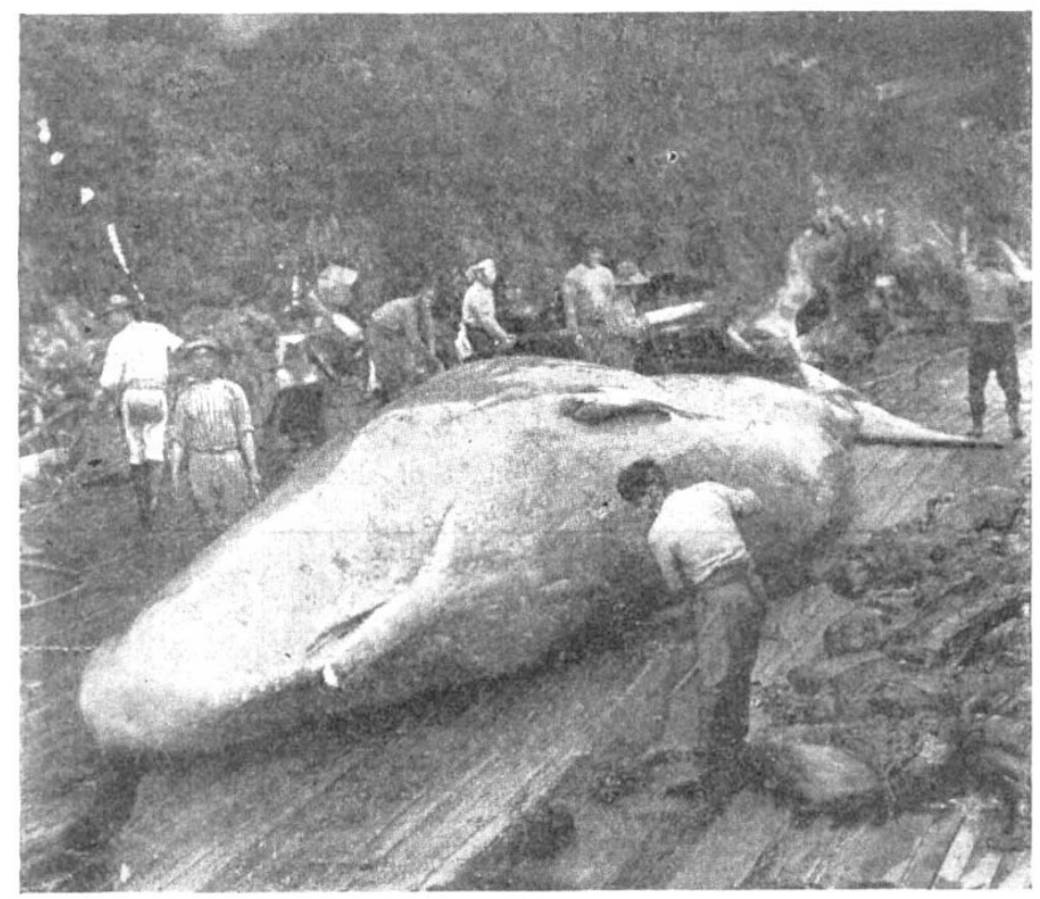

Fil: 4, -A Female Sperm Whale.

Dr. F. W. True, assistant secretary of the Smithsonian Institution, published in $x 904$ a great work entitled "The Whalebone Whales of the Western North Atlantic," in which he discussed the relationship of the Atlantic whales; this book was made possible in its present complete form only by study at the Newfoundland shore-stations. Other shorter papers, too numerous to mention, which have greatly increased our knowledge of these interesting animals, have appeared within the last ten or fifteen years, many of them illustrated with photographs of the whales described.

The Norwegian method of capture has also made possible, and, in fact, comparatively easy, a study of the habits of the large whales.

The ships which hunt from these shore-stations are trim little vessels, about go or soo feet in length, and although they can scarcely be called comfortable, they furnish a not uninviting home for a short stay, if one

NO. 2200, VOL. 88] is a good sailor. From the deck the movements of the whales can be easily seen and studied, and many opportunities are given to secure photographs of living animals. Often such pictures show many things that would otherwise have been unnoticed.

The directors of the shore-whaling companies and the managers of the stations have always been very willing to assist in the study of the animals which form the basis of their industry, and have generously allowed the use of their ships and stations. Not only this, but they have in many instances gone to considerable trouble to secure specimens that could be prepared and presented to museums for the purpose of exhibition and osteological study. Thus the old saying that "It is an ill wind that blows good to no one" applies very decidedly to the whaling industry. It is, however, deeply to be regretted that the wholesale slaughter of whales will inevitably result in their early commercial extinction; but meanwhile science is profiting by the opportunities given for the study of these strange and interesting animals.

Roy C. ANDrews.

\section{THE IMPROVEMENT OF} INDIAN WHEAT.

THE idea prevails that Indian wheats are weak and do not behave well in milling; their chief points of excellence are their great dryness and, owing to the thinness of the bran, the large proportion of flour obtained from them when milled. Mainly as the result of trials, carried out by Messrs. MacDougal in I882, the cultivation of weak, soft white wheats for the purpose of export has been consistently advocated in India. Inquiry amongst the natives has shown, however, that a stronger type of wheat is preferred for their own use.

During the past few years the scientific selection and cultivation of these native strong wheats has been carried out at the Agricultural $\mathrm{Re}$ search Institute, Pusa, on lines similar to the experiments of Prof. Biffen at Cambridge. The results have established beyond doubt that strong, free-milling wheats, but little inferior to Manitoba wheats, can be grown at Pusa. The selected varieties have been submitted to Mr. A. E. Humphries during each of the last three years, and his report, which is included in the bulletin, indicates that they possess great potentialities as regards baking value. They are particularly adapted for special treatment with malt extract and yeast foods, behaving in this respect as Manitoban good-grade wheat produced in a dry season.

From the cultivator's point of view the vield of a variety of wheat is of more importance than the quality of its grain. Much attention has been paid to this point at Pusa, and it has been established that the limiting factors affecting yield in India are the length of the growth period, the water supply, and, particularly in dry districts, the strength of the straw.

1 "The Milling and Baking Qualities of Indian Wheat." By Albert Howard and Gabrielle L. C. Howard. Bulletin No. 22. Agricultural Research Institute, Pusa. Price $8 d$. 
It was at one time considered impossible to combine high quality and high yield, but it has been shown now, both at Cambridge and at Pusa, that this is not the case. Half a dozen wheats have been bred at Pusa which give high yields of both grain and straw.

The problem of producing strong wheats in India suitable both for consumption in the country and for export to England, and at the same time profitable to the growers, is considered solved. Two shortcomings of the Indian wheats still await improvement. These are want of standing power of the straw and want of rust-resisting power.

At the same time, the producing power of the soil at Pusa has been doubled by hot-weather cultivation (see Nature, February r7, roro), by moisture conservation, and by embanking with occasional green manuring. In this way a yield of 40 bushels to the acre has been produced without irrigation or manure.

It remains to be proved that the selected wheats will do equally well in the farmers' hands in other parts of India, and that the methods adopted at Pusa cin be applied elsewhere.

E. F. A.

\section{MY TROPIC ISLE. ${ }^{1}$}

THIS book, which is beautifully illustrated by appropriate photographs, as well as admirably written, is quite above the normal type of its class. within the area of tropical Australia. It was "an unpolluted isle, without history, without any sort of fame ... the most fascinating, the most desirable on the coast of North Queensland," when permanent settlement began on September 28, 1897.

The author landed on this tropic isle weighing a little more than eight stone, and in a frail physical state, yet "trees had to be felled and sawn into proper lengths for piles.... With blistered and bleeding hands, aching muscles, and stiff joints he persevered." Whilst the house was being built they lived in tentsthe "they" standing apparently vaguely, first for the author and a few friends, then, it may be conjectured, for a wife and children. Meanwhile, the Australian blacks they had brought with them obtained fish from the sea coast and killed scrub fowl and pigeons. Gaps in the provender were filled up with tinned meat and bread and jam. Later a small area of forest land and a patch of jungle were cleared for the cultivation of maize, sweet potatoes, and vegetables. Fruit-trees were planted, and have since "been in the ascendant to the detriment of other branches of cultural enterprise."

The gradual emergence of a fairly civilised and comfortable house, of a regularly supplied larder from the wild gifts of nature, from farm and plantation, is quite as fascinating as the opening chapters of "Robinson Crusoe." Then we are made acquainted with the other inhabitants of the isle, insects, such as

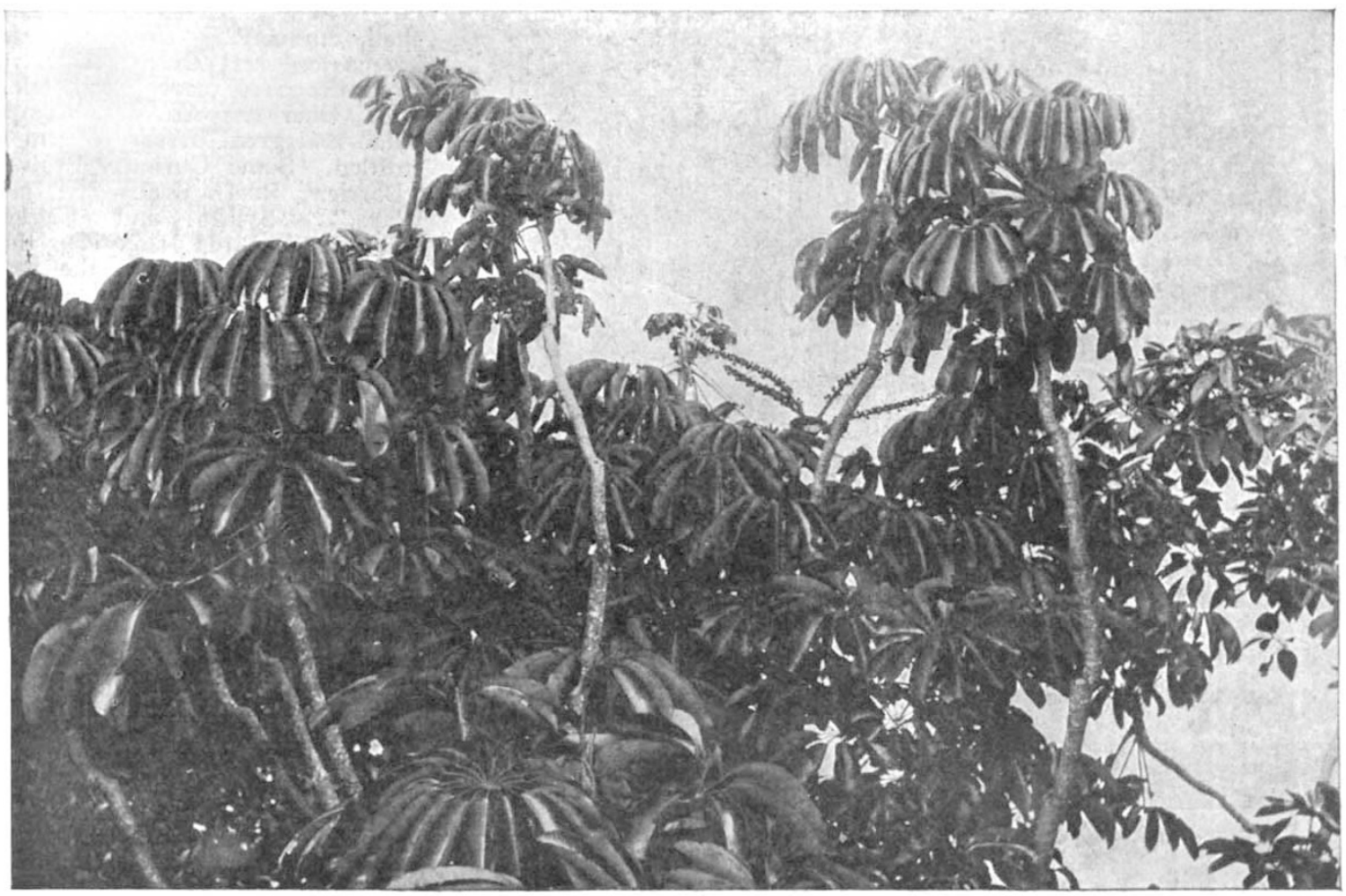

FIG. 1.-Umbrella Tree (Brassaia actinophylla). From "My Tropic Isle."

It is sufficiently romantic and surggestive of De Foe to avoid very clear geographical indications or maps to show the position of "My Tropic Isle," and one is left to infer that it is an island or islet not far from the coast of northern Queensland, and well 1 "My Tropic Isle." By E. J. Bantield. Pp. 3r5. (London T. Fisher Unwin, 19ru.) Price ros. $6 d$. net.

NO. 2200 , VOL. 88] large wasps, which build terra-cotta warehouses in which to store the semi-animate carcases of grubs; the solitary bees that turn by degrees favourite volumes into a solid block of waxen comb. These and many other insects and spiders are attacked by more or less fantastic lizards, and by bats, "sharp-toothed and with pin-point eyes, swooping in at one door and 